\title{
Distributive Politics and Economic Growth
}

\section{Citation}

Alesina, Alberto, and Dani Rodrik. 1994. Distributive politics and economic growth. Quarterly Journal of Economics 109, no. 2: 465-490.

\section{Published Version}

http://dx.doi.org/10.2307/2118470

\section{Permanent link}

http://nrs.harvard.edu/urn-3:HUL.InstRepos:4551798

\section{Terms of Use}

This article was downloaded from Harvard University's DASH repository, and is made available under the terms and conditions applicable to Other Posted Material, as set forth at http:// nrs.harvard.edu/urn-3:HUL.InstRepos:dash.current.terms-of-use\#LAA

\section{Share Your Story}

The Harvard community has made this article openly available.

Please share how this access benefits you. Submit a story.

Accessibility 


\title{
DISTRIBUTIVE POLITICS AND ECONOMIC GROWTH*
}

\author{
Alberto Alesina AND DANi RodRIK
}

We study the relationship between politics and economic growth in a simple model of endogenous growth with distributive conflict among agents endowed with varying capital/labor shares. We establish several results regarding the factor ownership of the median individual and the level of taxation, redistribution, and growth. Policies that maximize growth are optimal only for a government that cares solely about pure "capitalists." The greater the inequality of wealth and income, the higher the rate of taxation, and the lower growth. We present empirical results that show that inequality in land and income ownership is negatively correlated with subsequent economic growth.

A crude distinction between economics and politics would be that economics is concerned with expanding the pie while politics is about distributing it. In this paper we analyze the relationship between the two. We focus on how an economy's initial configuration of resources shapes the political struggle for income and wealth distribution, and how that, in turn, affects long-run growth. Our main conclusion is that inequality is conducive to the adoption of growth-retarding policies. We derive this result from a simple political-economy model of growth, and present cross-country evidence consistent with it.

The key feature of our model is that individuals differ in their relative factor endowments. We distinguish between two types of factors: an accumulated factor (called "capital") and a nonaccumulated factor (called "labor"). Growth is driven by the expansion of the capital stock, which is in turn determined by individual saving decisions. Long-run growth is endogenous, as the aggregate production function is taken to be linearly homogeneous in capital and (productive) government services taken together. The provision of government services is financed by a tax on capital.

Because government services are productive, a "small" tax on

\footnotetext{
*We would like to thank James Alt, Olivier Blanchard, Alex Cukierman, Allan Drazen, Kiminori Matsuyama, Maurice Obstfeld, Roberto Perotti, Torsten Persson, Lant Pritchett, Andrei Shleifer, and participants in seminars at the University of California at Berkeley; Boston College, Cornell, George Mason, and Harvard Universities; the International Monetary Fund; the University of Brussels, the University of Colorado, the University of Pennsylvania; Stanford University; Tufts University, University of California at Los Angeles, Yale University; and the National Bureau of Economic Research for useful suggestions; and Gerald Cohen and Nazrul Islam for excellent research assistance. Alesina gratefully acknowledges financial support from the Sloan Foundation. Rodrik gratefully acknowledges financial support from an NBER Olin Fellowship and a Hoover National Fellowship. 
capital benefits everyone. However, heterogeneity in the ownership of factors implies that individuals differ in their ideal rate of taxation. Since the tax on capital affects accumulation and growth, this difference also carries over to individuals' preferences over the ideal growth rate. An individual whose income derives entirely from capital prefers the tax rate that maximizes the economy's growth rate. Anyone else would prefer a higher tax, with a correspondingly lower growth rate. The lower an individual's share of capital income (relative to his labor income), the higher is his ideal tax, and the lower his ideal growth rate.

How is the actual choice of policy determined by individual preferences? The median voter theorem, according to which the tax rate selected by the government is the one preferred by the median voter, provides a useful benchmark. Using this theorem, we establish our main result on the relationship between income distribution and growth. The more equitable is distribution in the economy, the better endowed is the median voter with capital. Consequently, the lower is the equilibrium level of capital taxation, and the higher is the economy's growth. Furthermore, in our model the distribution of income is monotonically related to the distribution of capital. Thus, the central theoretical result that we shall test is that income and wealth inequality are inversely related to subsequent economic growth.

While an explicit analytical model is indispensable to lay out the logic of our story, the specific formalization we have chosen should be viewed as an illustration of a more general idea. When we use the term capital, for example, what we have in mind are all growth-producing assets, including physical capital, human capital, and proprietary technology. Labor, in turn, stands for unskilled labor. More importantly, our tax on capital must be interpreted as a metaphor for any kind of redistributive policy that transfers income to unskilled labor while reducing the incentive to accumulate. Governments have a wide variety of such policies at their disposal, and we shall mention some of them below.

Similarly, our use of the median-voter theorem should not be taken as a literal description of the political process we have in mind. We appeal to this theorem simply to capture the basic idea that any government is likely to be responsive to the wishes of the majority when key distributional issues are at stake. Even a dictator cannot completely ignore social demands, for fear of being overthrown. Thus, even in a dictatorship, distributional issues affecting the majority of the population will influence policy 
decisions. With these nuances kept in mind, our central idea becomes a simple and intuitive one: distributive struggles harmful to growth are more likely to take place when resources are distributed unevenly.

We present some empirical results consistent with our model at the end of the paper. Our model implies an inverse relationship between growth and the prior levels of both income and wealth equality. Measures of wealth distribution are hard to find, except for a measure of distribution of land ownership. Therefore, we focus on this measure of land distribution and on measures of income distribution. Controlling for initial levels of income and human capital, we find a statistically significant negative correlation between inequality in land distribution (measured around 1960) and economic growth over the subsequent two and a half decades. We obtain the same kind of results for income distribution as well: initial inequality in income is negatively correlated with subsequent growth.

Our work is related to four distinct strands in the economics literature. First, our model fits in with the tradition of the new literature on endogenous growth [Romer 1986; Lucas 1988; Barro 1990; Barro and Sala-i-Martin 1990] and extends it by showing how distributional considerations affect the choice of growth in a political equilibrium. Second, our basic ideas are related to the political-economy literature on majority voting on tax rates [Romer 1975; Roberts 1977; Meltzer and Richard 1981; Mayer 1984] and build a bridge between this literature and the new growth models. While the literature on voting on tax rates is static, our model is dynamic. Third, the questions we examine are reminiscent of some perennial issues in the development literature [Kuznets 1955; Fields 1980]. This body of work has traditionally been concerned with the distributional implications of growth. Here we reverse the question and ask how distribution affects growth. Finally, a recent literature has emphasized links between income distribution and growth that operate through nonpolitical channels. In particular, Murphy, Shleifer, and Vishny [1989] were the first to argue that income distribution influences the size of home demand, and hence the potential for industrialization. This paper has empirical implications on the relationship between income distribution and growth which are similar to ours. Also, Galor and Zeira [1993] show that in models with liquidity constraints income distribution determines the share of the population that can invest in educa- 
tion: the relationship between inequality and growth is positive at low levels of income, but negative otherwise.

Several papers have recently explored political models linking income distribution and growth. The two papers most closely related to ours are Bertola [1993] and Persson and Tabellini [1991], both of which were written independently of ours. Bertola presents a model focusing on the distinction between accumulated and nonaccumulated factors of production and points to the conflict of interest regarding growth that exists among individuals with differing sources of income. Persson and Tabellini develop a model that, although it has empirical implications similar to ours, is quite different. They consider a simplified overlapping-generations framework, where agents live for two periods: income is taxed purely for redistributive purposes, and taxation influences investment in human capital. In our model agents have an infinite horizon, and taxes are not used only for redistributive purposes. Tax revenues provide a public good necessary for private production. Thus, our model (unlike that of Persson and Tabellini) is consistent with the inverted U-curve relationship between taxes and growth as in Barro [1990|. Persson and Tabellini also present empirical evidence consistent with ours, but using somewhat different data sets. Thus, our empirical results and theirs should be viewed as mutually reinforcing.

Finally, Perotti [1993], Saint-Paul and Verdier [1992], and Fernandez and Rogerson [1992] also develop various politicoeconomic models where income distribution affects the equilibrium level of investment in human capital and hence ultimately determines growth. Benhabib and Rustichini [1991] present a gametheoretic model in which individuals can appropriate society's resources to their own benefit (at the cost of future retaliation by others) and analyze the relationship between the level of wealth, income distribution, and growth. ${ }^{1}$

The plan of the paper is as follows. Section I lays out the basic theoretical framework and discusses the links among factor ownership, redistributive policy, and economic growth. Section II presents our empirical evidence. Section III concludes.

\section{THE THEORY}

We use a simple endogenous growth model with labor and capital as the primary factors of production. In addition, we assume

1. See Perotti | $1992 \mid$ for a succinct survey of this rapidly growing literature. 
that private production requires the provision of public services, which for concreteness we can think of as "law and order" services. Endogenous growth requires nondiminishing returns to the economy's reproducible resources. We obtain this feature by assuming that output is linear in capital and public services taken together. This yields our aggregate production function:

$$
y=A k^{\alpha} g^{1-\alpha} l^{1-\alpha}, \quad 0<\alpha<1,
$$

which is adapted from Barro [1990] and Barro and Sala-i-Martin [1990], with slight modification. $A$ is a technological parameter, $k$ and $l$ are the aggregate stocks of capital and labor, respectively, and $g$ is the aggregate level of government spending on productive services. The single good produced in this economy can be used for either consumption or investment, and we fix its price at unity. To save on notation, we shall not show the time dependence of each variable, unless doing so is required to avoid confusion. The appeal of this model for our purposes is that it attributes a constructive role for government. Therefore, redistributive policies will interact with growth-enhancing policies. This feature is realistic: fiscal redistribution often takes place through various spending programs above and beyond direct cash transfers.

To finance spending on public services, the government has access to a tax on capital income, $\tau$. The budget is balanced every instant, so that

$$
g=\tau k \text {. }
$$

The policy options are restricted in two important respects. First, we rule out expropriation of capital. Since capital taxation is distortionary, the government could improve welfare by expropriating the capital stock and then publicly operating it and distributing the profits. Alternatively, the government could expropriate the capital stock and rent it. These policies would achieve the command optimum and maximize welfare even from the point of view of a government that cares only about capital owners. ${ }^{2}$ We leave out considerations of expropriation, to avoid dealing with timeinconsistency problems in capital taxation, which are not our focus. The reason why expropriation is not more common in the real world is clearly outside the scope of the model. Second, we allow only a linear tax on capital and hence rule out progressivity of tax

2. On time-inconsistency of this kind see Fischer $\lceil 1980]$ and the discussion in Rodrik [1993] regarding a government that has a redistributive motive. 
rates on capital. In this type of model the median voter has an incentive to impose progressive taxation, which falls primarily (or exclusively) on income recipients richer than the median. Note, however, that even with a linear tax rate on capital, as long as wage income is relatively evenly distributed, our model will effectively yield a form of progressive taxation, with richer individuals (with higher capital income) being taxed more heavily than poorer ones.

Capital is to be interpreted in the broad sense indicated in the introduction, namely, as including physical capital, human capital, and all proprietary technology. The tax on capital, therefore, should be viewed as a tax on all resources that are accumulated, including human capital. The (unskilled) labor force, which we take to be constant, is not subject to taxation. This assumption is built into the model to allow the government to discriminate between these two types of factors of production and to undertake redistributive policies. We could, in principle, allow taxes on labor income as well, without greatly altering our qualitative conclusions, but the analytics would get considerably more complicated. ${ }^{3}$ We shall provide further justification for this asymmetry below.

We assume perfect competition in factor markets so that wages and rates of return on capital are determined by the usual marginal productivity conditions. Taking the appropriate partial derivatives of (1) and substituting from (2), we obtain

$$
\begin{gathered}
r=\frac{\partial y}{\partial k}=\alpha A \tau^{1 \alpha} \equiv r(\stackrel{+}{\tau}) \\
w=\frac{\partial y}{\partial l}=(1-\alpha) A \tau^{1-\alpha} k \equiv \omega(\tau) k .
\end{gathered}
$$

We assume that labor is supplied inelastically, which allows us to set the economy's aggregate labor endowment $(l)$ equal to unity. Note that the marginal productivity of capital $(r)$ is independent of the capital stock, once the tax on capital that finances government spending is taken into account. This prevents diminishing returns from setting in. Furthermore, the marginal productivities of labor and capital are both increasing in the tax rate on capital, as higher

3. Two analytical complications in particular would arise. First, we would have to allow for a labor supply decision (i.e., labor-leisure choice) to make sure that labor taxation induces resource costs. Second, we would not be able to appeal directly to the median-voter theorem, as voting would have to take place over two separate tax rates. Restrictions on preferences are needed for the median-voter theorem to hold in multidimensional voting problems. Our main point, that different individuals have different preferences over the taxation of capital, survives this generalization. Therefore, we think that setting the labor tax to zero is an acceptable shortcut. 
taxes allow more government spending on productive services for any given level of $k$. The wage rate is also increasing in the capital stock. Net of taxes, capital and labor income are given by

$$
\begin{gathered}
y^{k}=[r(\tau)-\tau] k \\
y^{l}=\omega(\tau) k .
\end{gathered}
$$

For the national income identity to be satisfied, it is necessary that $y^{k}+y^{l}+g=y$, which is indeed the case here.

At this point we note that the tax on capital plays two critical roles in this model. First, and most directly, it affects the net return to owners of capital, and hence will alter the incentive to accumulate. Second, it increases the instantaneous level of wage income (while reducing its rate of growth insofar as it also induces a lower rate of capital accumulation). Wage income is increasing in $\tau$ because a higher rate of taxation allows the government to increase its spending on services that increase productivity.

Although we have modeled here a particular policy instrument (a tax on capital income) and a particular channel through which this instrument enhances labor income (government spending on productive services), our framework is meant to capture a much broader set of redistributive policies. Indeed, the type of redistributive policies we have in mind takes many different guises in practice and can be modeled in many different ways. Consider some examples.

1. In an economy where wage income is relatively evenly distributed, a progressive income tax yields a higher effective tax rate on capital income than on labor income. This shifts the tax burden from labor to capital. Furthermore, if capital includes human capital, a progressive tax on labor income redistributes from owners of human capital to owners of unskilled labor.

2. In an open economy import tariffs redistribute income from the economy's abundant factor of production to its scarce factor of production [Stolper and Samuelson 1944]. Therefore, in an economy like that of the United States which is rich in capital, import restrictions are effectively a tax on capital and a subsidy on (unskilled) labor.

3. In economies where labor relations are organized along corporatist lines (e.g., in some Western European countries), direct state intervention in collective bargaining can alter contract terms (for wages, benefits, and the like) to the advantage of workers, depressing the return to capital. 
No single model can capture these and other ways in which redistribution takes place in practice. What should be clear, however, is that the policies listed above will all work in pretty much the same manner as a direct tax on capital. ${ }^{4}$

So our model is not meant to suggest that governments do not have other taxes besides capital taxes. Nor do we want to imply that capital taxes are the only policies that can redistribute. We are simply saying that in practice most policies that redistribute from capital to labor will have qualitatively the same impact as our capital tax.

\section{A. Determinants of Growth}

We assume that individuals are alike in all respects except for their initial ownership shares in the economy's aggregate stocks of capital and labor. Each individual is indexed by his relative factor endowment $\sigma^{r}$ :

$$
\sigma^{i}=\frac{l^{i}}{k^{i} / k}, \quad \sigma^{i} \in[0, \infty) .
$$

(Remember that the aggregate labor endowment of the economy is normalized to unity.) An individual with a high o is capital-poor, while one with low $\sigma$ is capital-rich. In principle, $\sigma^{i}$ may change over time; however, it will turn out, in our case, that $\sigma^{i}$ will remain constant. Each individual can earn income from both capital and labor. Therefore, using (5) and (6),

$$
y^{i}=\omega(\tau) k l^{i}+[r(\tau)-\tau] k^{i}=\omega(\tau) k^{i} \sigma^{i}+[r(\tau)-\tau] k^{i} .
$$

Note that income depends both on individual ownership of capital and on the aggregate stock of capital.

We assume that all individuals have the same logarithmic utility function. The consumption-saving decisions of the $i$ th individual are determined by solving the following problem:

$$
\max U^{i}=\int \log c^{i} e^{{ }^{0 t}} d t
$$

4. Nute also that we could model the transfer mechanism very differently, without relying on the provision of government services. Suppose, for example, that $g$ stands for a productivity parameter (external to individual firms). Assume further that productivity $g$ increases linearly in $k$. These assumptions then ensure that the model will exhibit endogenous growth. To model the transfer from capital to labor, we could then simply assume that the proceeds of the tax on capital are spent in the form of a wage subsidy. With these changes we would have a model that is very similar to the one that is described in the text. 
such that

$$
\frac{d k^{i}}{d t}=\omega(\tau) k^{i} \sigma^{i}+[r(\tau)-\tau] k^{i}-c^{i}
$$

where $c^{i}$ denotes consumption and $\rho$ is the discount rate. The individual consumer takes the paths of $r, k$, and $\tau$ as given. The solution to this problem is given by the following equation:

$$
\hat{c}^{i}=(r(\tau)-\tau)-\rho, \quad \text { for all } i,
$$

where a circumflex denotes proportional changes (i.e., $\hat{x}=(d x / x) /$ $d t$ ).

Now assume that $\tau$ remains unchanged over time. (We shall show in the next subsection that this will be the case in equilibrium.) Each individual then accumulates along a steady-state path given by

$$
\hat{k}^{i}=\hat{c}^{i}=r(\tau)-\tau-\rho \equiv \gamma(\tau) .
$$

This has the helpful implication that all individuals accumulate at the same rate. Therefore, there is a common economywide growth rate $\gamma(\tau)$, which is independent of the initial distribution of factor endowments. Moreover, the relative factor endowments $\sigma^{i}$ remain constant over time, and the distribution of factor ownership is time-invariant.

These results generalize to any time-separable, isoelastic utility function. Suppose that instantaneous utility took the more general form $\left(c^{1-\eta}-1\right) /(1-\eta)$, instead of $\log (c)$. The corresponding accumulation rate (under constant $\tau$ ) would have become $\hat{k}^{i}=$ $\hat{c}^{i}=\eta^{-1}(r-\tau-\rho)$, which is also independent of initial factor ownership shares. The crucial implication of this utility function which makes our model tractable is that wealth (and income) distribution is constant over time. If it were not, the voting process would become much more complicated, since the identity of the median voter would change over time, leading to strategic intertemporal voting (as will become clear below).

As shown in (11), growth is linear in the difference between the after-tax return to capital and the discount rate. It has the following properties:

$$
\gamma_{\tau} \equiv \frac{\partial \gamma}{\partial \tau}=\frac{\partial r}{\partial \tau}-1 \gtrless 0 \quad \text { as } \quad \tau \lessgtr[\alpha(1-\alpha) A]^{1 / \alpha} .
$$

The higher is the after-tax return to capital, the higher the 
economy's growth rate. The tax on capital has a nonlinear effect on growth. For small tax rates the productivity-enhancing effect of public spending dominates, and the after-tax return to capital increases in $\tau$. For large tax rates, the after-tax return to capital falls as $\tau$ is raised further. Therefore, the relationship between the economy's growth rate and the tax on capital is represented by an inverse U-curve: the growth rate first increases, and then decreases, as $\tau$ is progressively raised. The growth-maximizing tax rate is given by

$$
\tau^{*}=[\alpha(1-\alpha) A]^{1 / \alpha},
$$

where $\tau^{*}$ is determined by technological parameters and is timeinvariant.

\section{B. Policy Preferences with Heterogeneity in Factor Ownership}

What is individual $i$ 's preferred policy, and how does it depend on $\sigma^{i}$ ? To answer this question, we look at the problem that would be solved by a government that selects $\tau$ in order to maximize $i$ 's well-being. We note first that, along the optimal path, the instantaneous level of consumption is given by

$$
c^{i}=\left[\omega(\tau) \sigma^{i}+\rho\right] k^{i}
$$

(from [9] and [10]). Hence individual $i$ consumes his entire labor income $\left(\omega(\tau) \sigma^{i} k^{i}\right)$ plus a fraction of his capital stock $\left(\rho k^{i}\right)$. The relevant maximization problem for the government then becomes

$$
\max _{\top} U^{i}=\int \log c^{i} e^{\text {nt }} d t
$$

such that

$$
\begin{aligned}
c^{i} & =\left[\omega(\tau) \sigma^{i}+\rho\right] k^{i} \\
\hat{k}^{i} & =\gamma(\tau) \\
\hat{k} & =\gamma(\tau) .
\end{aligned}
$$

The constraints make clear that the choice of policy affects both the level of consumption and its growth rate. The economywide growth equation $\hat{k}=\gamma(\tau)$ belongs here as a constraint because $k$ enters the definition of $\sigma^{i}$.

This exercise yields the following implicit characterization of individual $i$ 's most preferred tax, $\tau^{i}$ :

$$
\tau^{i}\left\{1-\alpha A(1-\alpha)\left(\tau^{i}\right)^{-i x}\right\}=\rho(1-\alpha) \theta^{i}\left(\tau^{i}\right),
$$


where

$$
\theta^{i}\left(\tau^{i}\right)=\omega\left(\tau^{i}\right) \sigma^{i} /\left[\omega\left(\tau^{i}\right) \sigma^{i}+\rho\right] .
$$

$\theta^{i}($.$) is the share of the labor-income component in consumption$ expenditures of individual $i$, and it is increasing in $\sigma^{i}{ }^{5}$ Since time does not enter these expressions, the government's optimal policy involves a constant tax rate over time. Hence individual behavior based on a fixed $\tau$ is fully consistent with the actual equilibrium outcome.

It can be verified that (15) and (16) yield a unique $\tau^{i}$ which increases with $\sigma^{i}$. In words, the more capital-poor is an individual, the higher is his ideal tax on capital. One interesting benchmark case is provided by a pure capitalist, who has no labor income. In this case $\sigma^{k}=0$, where the superscript $k$ identifies this type of individual. Equation (15) yields the pure capitalist's ideal tax to be

$$
\tau^{k}=[\alpha(1-\alpha) A]^{1 / \alpha}=\tau^{*} .
$$

In view of the role played by public services in the aggregate production function, it is not surprising that the capitalist desires a positive rate of taxation. But as this expression makes clear, his ideal tax is precisely the one that maximizes the economy's growth, $\tau^{*}$.

Since $\tau^{i}$ is increasing in $\sigma^{i}$, an immediate implication is that an individual with some labor income (i.e., with $\sigma^{i}>0$ ), no matter how small this income is, prefers a tax rate that exceeds $\tau^{*}$ and a growth rate that falls short of the maximum, $\gamma\left(\tau^{*}\right)$. In particular, if wealth were evenly distributed in the economy, the representative individual (with $\sigma^{i}=1$ ) would pick $\tau^{i}>\tau^{*}$. Consequently, a government that maximized the welfare of the representative individual would not want to maximize the economy's growth rate. This indicates that growth and welfare are not the same in our context.

The intuition behind these results is best seen by distinguishing between level and growth effects of tax policy. Along the optimal consumption path a pure capitalist (with $\sigma^{i}=0$ ) consumes a constant fraction of his capital stock (given by $\rho k^{i}$, see (13), and the instantaneous level of his consumption is therefore independent of $\tau$. The value of his consumption stream is maximized by simply selecting the level of $\tau$ that maximizes the rate of capital

5. For more detail on the derivations of these results, the reader is referred to the working paper version of this paper [Alesina and Rodrik 1991 ]. 
accumulation. For anyone else the instantaneous level of consumption has a labor-income component also, which depends on $\tau$ (see (13). Whenever $\tau>\tau^{*}$, an increase in taxation has two distinct effects. First, it raises the level of consumption of any individual who receives labor income, and second, it reduces the rate of growth of aggregate income (including real wages) and consumption.

Now consider an initial situation with $\tau$ set at the growthmaximizing $\tau^{*}$. A slight increase in $\tau$ would have only a secondorder effect on accumulation (since growth is at its maximum), and hence only a second-order effect on the growth rate of consumption. But it would have a positive first-order effect on the instantaneous consumption level of any individual who receives labor income. On net, this increase in $\tau$ must therefore be beneficial, for anyone except a pure capitalist. This explains why the trade-off will always result in a level of taxation that exceeds the growthmaximizing one, except in the limiting case of a pure capitalist. Further, the larger is the share of labor income for an individual, the more significant is the level effect, and the higher the ideal tax.

\section{Policy Choice under Majority Voting}

Suppose now that the decision over the tax rate is reached by pairwise comparison under simple majority rule. The median-voter theorem can be applied to this case because voting takes place over a single issue, preferences are single peaked, and there exists a monotonic relationship between ideal policies and voters' factor endowments. In addition, since the ideal policies are constant over time and the distribution of factor endowments is also time invariant, it does not matter whether voting takes place only once at time zero or is repeated every period. ${ }^{6}$ We can conclude that the tax rate chosen by majority rule, $\tau^{m}$, is defined implicitly by the following equation, where $\sigma^{m}$ denotes the relative factor-endowment share of the median voter:

$$
\tau^{m}\left\{1-\alpha A(1-\alpha)\left(\tau^{m}\right)^{-\alpha}\right\}=\rho(1-\alpha) \theta^{m}\left(\tau^{m}\right),
$$

where

$$
\theta^{m}\left(\tau^{m}\right)=\omega\left(\tau^{m}\right) \boldsymbol{\sigma}^{m} /\left[\omega\left(\tau^{m}\right) \sigma^{m}+\rho\right]
$$

(compared with (15) and (16)). Under majority voting, the political equilibrium yields a tax rate that is the ideal tax rate of the median voter - the latter identified by his relative factor endowment $\sigma^{m}$.

6. The importance of our restrictions on the utility function that lead to a time-invariant distribution of wealth is now clear. 
Equation (18) establishes a relationship between the distribution of factor ownership and growth. In a perfectly egalitarian society everyone has the same labor/capital share, that is, $\sigma^{m}=$ $\sigma^{i}=1$ for all $i$. In actual, real-world distributions, the labor/capital share of the median voter is above the average share; that is, $\sigma^{m}-$ $1>0$. Furthermore, the greater the inequality, the larger is the difference between median and average likely to be. Hence, we can treat $\left(\sigma^{m}-1\right)$ as the relevant indicator of inequality in the context of our model. This measure captures how much below the average share lies the median share of capital ownership. For example, a very high $\sigma^{m}$ implies that 50 percent of the voters own a very low share of the economy's capital stock.

As mentioned before, factor ownership is directly related to income in this model. In fact, our results can be easily restated in terms of income inequality. To see this, note that by rearranging (8) we can express individual $i$ 's income as

$$
y^{i}=\left[\omega+(r-\tau)\left(1 / \sigma^{i}\right)\right] l^{i} k .
$$

Since labor in our model refers to unskilled labor, it would seem natural that all individuals would have more or less a common value for $l^{i}$ (that is, 24 hours). A direct implication is that $y^{i}$ will be inversely related to $\sigma^{i}$. Consequently, the larger the gap between $\sigma^{m}$ and unity, the larger the gap that will exist between median and average incomes. Equation (18) therefore leads to the following important result.

The higher is $\sigma^{m}$ above unity, the lower is the rate of growth of the economy. Or, in more practical terms, the more unequal is the distribution of income and wealth, the lower is the rate of growth.

In the context of our model, "inequality" is given by how poor is the median relative to the average voter. It is of course possible to imagine distributions with different degrees of inequality which have the property that the difference between median and average voter remains identical. The crucial role played in our model by the median-average gap stems from the application of the medianvoter theorem. As emphasized in the introduction, we view this theorem as a convenient and elegant way of capturing a more general point. The specific index of inequality $\left(\sigma^{m}-1\right)$ resulting from this theorem has to be viewed in the same light.

For growth to be as high as possible, we need the median voter to own as much capital as possible, and to have as high an income (relative to the average) as possible. When a large segment of the electorate is cut off from the expanding and income-generating 
assets of the economy, it is more likely to be willing to tax income from these assets and to undercut growth. ${ }^{7}$ Note that it is practically impossible for majority voting to yield the economy's maximum growth rate. Maximum growth is attained only if the median voter has no labor endowment whatsoever, which is not a realistic possibility. But, as discussed above, this result has little normative significance, since maximizing growth does not maximize the "representative" individual's welfare in this context.

Finally, a word on dictatorships versus democracies. In principle, our model should be more directly applicable to democracies, where voting plays a significant role in policy making. Thus, the relationship between income distribution and growth should be stronger in democracies than in dictatorships. However, dictators' policy decisions are also influenced by social demands and social conflicts. For instance, a large group of impoverished workers or landless peasants may threaten the stability of the regime and force the leadership to implement growth-retarding redistributions.

Our model does not imply any type of correlation between regime type (democracy versus dictatorship) and growth for two reasons. First, as argued above, redistributive pressures may find a political outlet not only in democracies but also in dictatorships. Second, the weight placed on growth in a dictatorship would depend on the nature of the regime and its preferences. A pro-capital (or technocratic) regime would minimize redistribution and maximize growth, while a populist regime would do the opposite. ${ }^{8}$ Thus, the model does not predict a systematic difference in the average rates of growth of democracies and nondemocracies.

\section{EMPIRICAI, Evidence}

The basic implication of our model is that the more unequal is the distribution of resources in society, the lower is the rate of economic growth. The link between distribution and growth is given by redistributive policies. In less equal societies more redistri-

7. This is related to the work by Romer [1975], Roberts [1977], and Meltzer and Richards [1981] on voting over linear tax rates on labor income. These authors analyze a static model in which an income tax has to be chosen, and show that the more unequal is the distribution of productivities (thus pretax income) the higher is the tax rate (and the transfer level) desired by the median voter. In a similar vein Mayer [1984] links factor ownership to desired trade interventions. Our discussion extends these results to a dynamic framework with endogenous growth.

8. In the working paper version of this paper |Alesina and Rodrik 1991|, we develop this point in more detail. 
bution is sought by a majority of the population. However, redistributive policies, in turn, reduce growth by introducing economic distortions.

The most direct way of testing the theory would be to relate measures of income (or wealth) inequality to measures of redistributive policies. The problem in pursuing this line of attack is that in different countries and time periods redistributive policies are pursued by different means. In our model we focus on capital taxation because this is the simplest way of formalizing redistributive policy. But as emphasized above, redistribution could be achieved by many other means: by a progressive income tax system, by minimum wage laws, by imposing trade and capital restrictions, and by the composition of government expenditures, just to name a few examples. It would be an almost impossible task to construct a meaningful cross-country index for the totality of such measures. For our purposes it does not matter which policy instruments are used to achieve redistribution. The only relevant point is that redistributive policies introduce distortions, and thereby reduce growth. Hence we focus our examination directly on the relationship between distribution of resources and growth. We attempt to determine whether initial inequality is a statistically significant predictor of long-term growth across countries.

Comparable data on wealth distribution for a large enough sample of countries do not exist. What we do have are distributional indicators on income and on land. With respect to income there exist several compilations of Gini coefficients and other indices drawn from national surveys [Jain 1975; Lecallion et al. 1984; Fields 1989]. Some countries have distributional indicators available for different time periods, but the intertemporal and cross-country comparability of these data is quite weak. Fields [1989] has recently reviewed the sources of income distribution estimates for 70 developing countries and has found that only 35 of them have data that satisfy minimum criteria of quality and comparability. ${ }^{9}$ The problem of data quality is less acute for developed countries. Therefore, we define and use a "high quality sample" that includes all the OECD countries for which we have data (from Jain [1975]) and the developing countries chosen by

9. His four criteria are (i) the estimates must be based on an actual household survey or census; (ii) the survey or census must be national in coverage; (iii) the data must be tabulated in enough categories that a meaningful index can be calculated if one is not already published; and (iv) for more than one year to be included, the surveys must have been comparable. See Fields and Jakubson [1993, pp. 3-4|. 
Fields [1989]. ${ }^{10}$ In addition, we present results for a larger sample, which includes all countries for which we have distributional data. For a list of countries with sources, see the Appendices.

With respect to land distribution we are aware of only one compendium [Taylor and Hudson 1972], and this source provides the Gini coefficient of land distribution for 54 countries around $1960 .{ }^{11}$ Land is only one component of wealth, and thus the Gini coefficient of land ownership is only a very imperfect proxy of a true measure of wealth distribution. Moreover, land does not exactly fit our model's notion of capital as an accumulating asset. But inequality in land ownership is likely to be highly correlated with inequality in the distribution of accumulating assets also. Since only Gini coefficients are available for land, we restrict the presentation of results to Gini coefficients for income as well. (However, we have also done work with quantile measures of income distribution and have reached very similar results; these additional results are available upon request.) The correlation coefficient between the land and income Gini's is 0.35 in the sample of 41 countries for which both indicators are available.

To avoid reverse causation from growth to distribution, we tried to limit the sample to countries for which we had Gini coefficients measured not too far beyond the beginning of the time horizon for growth. In the case of Gini coefficients for land, this did not prove to be a problem because the most recent data point comes from 1964 and the majority of Gini's date from before 1960 . However, many of the earliest income Gini coefficients are measured in the 1960s, and some in the 1970s (see the Appendices for details). Throwing out all of these cases would have reduced our sample size significantly. We have dealt with the simultaneity problem in two ways: first, by running two-stage least squares regressions and instrumenting for the Gini coefficients, ${ }^{12}$ and second, by running regressions for the 1970-1985 period as well as for the 1960-1985 period.

10. Of the 35 countries in the Fields sample, we could use only 29 because 4 of them were not in the Barro-Wolf $\{1989 \mid$ data set (Bahamas, Puerto Rico, Reunion, and Seychelles) and 2 had data only for the 1980 s (Cote d'Ivoire and Peru). The high-quality sample is made up of these 29 plus 17 developed countries from Jain | 1975 |. See the Appendix for a complete listing of countries and sources. Turkey, an OECD member, is included in the Fields sample of developing countries.

11. In our regressions, we actually use only 49 of these countries as the rest (Puerto Rico, Libya, Vietnam, Poland, and Yugoslavia) are not included in the Barro-WoIf [1989] 118-country data set from which our other data are drawn.

12. The instruments we use are listed in the notes to Table I. We have experimented with alternative sets of instruments, and found that the results are generally robust. 
In addition to the Gini coefficients, we have included in our regressions two additional explanatory variables emphasized in the recent growth literature [Barro 1991]: (i) the initial level of per capita income and (ii) the primary school enrollment ratio. The first variable is entered to account for the possibility of convergence, and the second is a measure of the initial level of human capital. We do not include investment in our regressions, as this is an endogenous variable in our model. Except for the Gini coefficients, all data are from Heston and Summers [1988] and Barro and Wolf [1989].

Table I shows our results for the 1960-1985 period. Columns (1) and (2) restrict the sample to countries for which income distribution data are more reliable: this is the high-quality sample described above. Columns (3) and (4) are the regressions for the larger sample of countries, where the previous sample is augmented by 24 additional developing countries. Columns (5)-(8) are the regressions that include the Gini coefficient for land, either alone or jointly with the income Gini (columns (6)-(8)).

The results indicate that income inequality is negatively correlated with subsequent growth. When either one of the two Gini's is entered on its own, the relevant coefficient is almost uniformly statistically significant at the 5 percent level or better and has the expected (negative) sign. The only exception is the OLS regression for the large sample (column (3)), where the income Gini is statistically significant only at the 10 percent level. We also note that the $t$-statistics for the land Gini are remarkably high (above 4), as are the $R^{2}$ 's for the regressions that include the land Gini's. When the land and income Gini's are entered together, the former remains significant at the 1 percent level, while the latter is significant only at the 10 percent level (the sample size shrinks to 41 countries in this case, since many countries have only one of the two indicators). The estimated coefficients imply that an increase in, say, the land Gini coefficient by one standard deviation (an increase of 0.16 in the Gini index) would lead to a reduction in growth of 0.8 percentage points per year.

Column (7) reports the results obtained including a dummy variable for democracies interacted with the land Gini. The coefficient is not statistically significant, rejecting the hypothesis that the relationship between inequality and growth is different in democracies and nondemocracies. We have included this interactive democracy dummy in all other versions of our regressions; the results were uniformly insignificant. By contrast, Persson and 
TABLE I

GROWTH REGRESSIONS FOK 1960-1985

\begin{tabular}{|c|c|c|c|c|c|c|c|c|}
\hline & \multirow{2}{*}{\multicolumn{2}{|c|}{$\begin{array}{l}\text { High-quality } \\
\text { sample } \\
(N=46)\end{array}$}} & \multirow{2}{*}{\multicolumn{2}{|c|}{$\begin{array}{c}\text { Largest possible } \\
\text { sample } \\
(N=70)\end{array}$}} & \multicolumn{4}{|c|}{ Largest possible sample } \\
\hline & & & & & \multicolumn{2}{|l|}{$(N=49)$} & \multicolumn{2}{|l|}{$(N=41)$} \\
\hline & $\begin{array}{l}\text { OLS } \\
(1)\end{array}$ & $\begin{array}{l}\text { TSLS } \\
(2)\end{array}$ & $\begin{array}{l}\text { OLS } \\
\text { (3) }\end{array}$ & $\begin{array}{c}\text { TSLS } \\
(4)\end{array}$ & $\begin{array}{l}\text { OLS } \\
\text { (5) }\end{array}$ & $\begin{array}{c}\text { OLS } \\
(6)\end{array}$ & $\begin{array}{l}\text { OLS } \\
(7)\end{array}$ & $\begin{array}{c}\text { OLS } \\
(8)\end{array}$ \\
\hline Const. & $\begin{array}{c}3.60 \\
(2.66)\end{array}$ & $\begin{array}{c}8.66 \\
(3.33)\end{array}$ & $\begin{array}{c}1.76 \\
(1.50)\end{array}$ & $\begin{array}{c}6.48 \\
(2.93)\end{array}$ & $\begin{array}{c}3.71 \\
(3.86)\end{array}$ & $\begin{array}{c}6.22 \\
(4.69)\end{array}$ & $\begin{array}{c}6.24 \\
(4.63)\end{array}$ & $\begin{array}{c}6.21 \\
(4.61)\end{array}$ \\
\hline GDP60 & $\begin{array}{c}-0.44 \\
(-3.28)\end{array}$ & $\begin{array}{c}-0.52 \\
(-3.17)\end{array}$ & $\begin{array}{c}-0.48 \\
(-3.37)\end{array}$ & $\begin{array}{c}-0.58 \\
(-3.47)\end{array}$ & $\begin{array}{c}-0.38 \\
(-3.61)\end{array}$ & $\begin{array}{c}-0.38 \\
(-3.25)\end{array}$ & $\begin{array}{c}-0.39 \\
(-3.06)\end{array}$ & $\begin{array}{c}-0.38 \\
(-2.95)\end{array}$ \\
\hline PRIM60 & $\begin{array}{c}3.26 \\
(3.38)\end{array}$ & $\begin{array}{c}2.85 \\
(2.43)\end{array}$ & $\begin{array}{c}3.98 \\
(4.66)\end{array}$ & $\begin{array}{c}3.70 \\
(3.72)\end{array}$ & $\begin{array}{c}3.85 \\
(4.88)\end{array}$ & $\begin{array}{c}2.66 \\
(2.66)\end{array}$ & $\begin{array}{c}2.62 \\
(2.53)\end{array}$ & $\begin{array}{c}2.65 \\
(2.56)\end{array}$ \\
\hline GINI60 & $\begin{array}{c}-5.70 \\
(-2.46)\end{array}$ & $\begin{array}{l}-15.98 \\
(-3.21)\end{array}$ & $\begin{array}{c}3.58 \\
(-1.81)\end{array}$ & $\begin{array}{l}-12.93 \\
(-3.12)\end{array}$ & & $\begin{array}{c}-3.47 \\
(-1.82)\end{array}$ & $\begin{array}{c}-3.45 \\
(-1.79)\end{array}$ & $\begin{array}{c}-3.47 \\
(-1.80)\end{array}$ \\
\hline GINILND & & & & & $\begin{array}{c}-5.50 \\
(-5.24)\end{array}$ & $\begin{array}{c}-5.23 \\
(-4.38)\end{array}$ & $\begin{array}{c}-5.24 \\
(-4.32)\end{array}$ & $\begin{array}{l}-5.21 \\
(-4.19)\end{array}$ \\
\hline $\begin{array}{l}\text { DEMOC* } \\
\text { GINILND }\end{array}$ & & & & & & & $\begin{array}{c}0.12 \\
(0.12)\end{array}$ & \\
\hline DEMOC & & & & & & & & $\begin{array}{c}0.02 \\
(0.05)\end{array}$ \\
\hline $\bar{R}^{2}$ & 0.28 & 0.27 & 0.25 & 0.26 & 0.53 & 0.53 & 0.51 & 0.51 \\
\hline
\end{tabular}

T'he dependent variable is average per capita growth rate aver 1960-1985. t-statistics are in parentheses. Independent variables are defined as follows:

GDP60: Per tapita GDP Jevel in 1960

PRIM60: Primary school enrollment ritio in 1960

GINI60: Gini coefficient of income inequality, measured cluse to 1960 (see Appendix fur dates)

GINILND: Gini coefficient of land distribution inequality, measured clost: $t_{0} 1960$ isee Appendix for datess DEMOC: Democracy dummy.

'Two-stage least squares regressions use GDP60, PRIM60, literacy rate in 1960, infint mortality in 1965. secondary enrollment in 1960 , fertility in 1965 , and an $A$ frica dummy as instrument.s.

Tabellini [1991] report that while the inverse relationship holds for democracies, it does not for nondemocracies. The difference in the results arises mostly because of different data sets on inequality, and to a lesser extent from some differences in specification and definition of democracies. ${ }^{13}$ Finally, column (8) indicates that

13. In a previous version of this paper, we reported weak support for the difference between democracies and nondemocracies using a data set closer to that of Persson and Tabellini [1991|. The present work employs a revised and improved data set, based on recent research by Fields [1993|. 
democracies do not grow faster than or more slowly than dictatorships.

The negative result in column (7) can be interpreted in two ways. One is that, as argued above, the pressure for redistribution coming from the majority is felt not only in democracies but also in other regimes. According to this view, some dictators are subject to political influences similar to those experienced by elected representatives. The alternative view is that income inequality influences growth through channels other than the political one. For instance, Murphy, Shleifer, and Vishny [1989] stress the role of home demand as shaped by income distribution.

Table II repeats these regressions for the 1970-1985 period (except for the two-stage least squares regressions). As mentioned above, this may be a more relevant time period to try our story out as many of our income Gini's are measured during the 1960s (and some in the 1970s). The results are indeed even stronger: the coefficient on the Gini is consistently significant at the 5 percent level or better. Moreover, both the land and income Gini's remain statistically significant (at the 1 percent and 5 percent levels, respectively) when they are entered jointly. The magnitude of the coefficients is commensurate with those in Table I.

Our results imply that countries that experienced a land reform in the aftermath of World War II and hence reduced the inequality in land ownership should have had higher growth than countries with no land reform. This argument is often mentioned in the literature on economic development as one explanation for the successful experience of several Asian countries, such as Japan, South Korea, or Taiwan, compared with the less stellar performance of most Latin American countries (see, for example, Ranis [1990] and Wade [1990, Chapter 8]). Asian countries had land reforms; Latin American countries did not.

Since our paper was first written and circulated in working paper form, more empirical work has been done on the relationship between income inequality and growth. Clarke [1993], in particular, has analyzed the robustness of the negative relationship between inequality and growth. He finds that the result is robust across different income inequality measures (Gini, quintile measures, Theil's index, etc.) and different specifications of the growth regression. Under most of his specifications, the hypothesis that democracies and nondemocracies differ in the relationship between inequality and growth is rejected. His findings, together with ours, 
'TABLE IJ

Growtil Regressions For 1970-1985

\begin{tabular}{|c|c|c|c|c|c|c|}
\hline & \multirow{3}{*}{$\begin{array}{c}\text { High- } \\
\text { quality } \\
\text { sample } \\
(N=46) \\
\begin{array}{c}\text { OLS } \\
(9)\end{array}\end{array}$} & \multirow{3}{*}{$\begin{array}{c}\text { Largest } \\
\text { possible } \\
\text { sample } \\
(N=70) \\
\text { OLS } \\
(10)\end{array}$} & \multicolumn{4}{|c|}{ Largest possible sample } \\
\hline & & & \multirow{2}{*}{$\begin{array}{c}(N=49) \\
\text { OLS } \\
(11)\end{array}$} & \multicolumn{3}{|c|}{$(N=41)$} \\
\hline & & & & $\begin{array}{l}\text { OLS } \\
(12)\end{array}$ & $\begin{array}{l}\text { OLS } \\
(13)\end{array}$ & $\begin{array}{l}\text { OLS } \\
(14)\end{array}$ \\
\hline Const. & $\begin{array}{c}4.56 \\
(2.67)\end{array}$ & $\begin{array}{c}2.80 \\
(2.00)\end{array}$ & $\begin{array}{c}4.88 \\
(3.16)\end{array}$ & $\begin{array}{c}7.22 \\
(3.79)\end{array}$ & $\begin{array}{c}7.18 \\
(3.69)\end{array}$ & $\begin{array}{c}7.22 \\
(3.74)\end{array}$ \\
\hline GDP70 & $\begin{array}{c}-0.29 \\
(-2.60)\end{array}$ & $\begin{array}{c}-0.27 \\
(-2.33)\end{array}$ & $\begin{array}{c}-0.21 \\
(-2.09)\end{array}$ & $\begin{array}{c}-0.28 \\
(-2.58)\end{array}$ & $\begin{array}{c}-0.28 \\
(-2.23)\end{array}$ & $\begin{array}{c}-0.27 \\
(-2.15)\end{array}$ \\
\hline PRIM70 & $\begin{array}{c}3.28 \\
(2.46)\end{array}$ & $\begin{array}{c}3.79 \\
(3.52)\end{array}$ & $\begin{array}{l}3.45 \\
(2.65)\end{array}$ & $\begin{array}{c}2.77 \\
(1.83)\end{array}$ & $\begin{array}{c}2.81 \\
(1.79)\end{array}$ & $\begin{array}{c}2.81 \\
(1.80)\end{array}$ \\
\hline GINI70 & $\begin{array}{c}-9.71 \\
(-3.62)\end{array}$ & $\begin{array}{c}-7.95 \\
(-3.49)\end{array}$ & & $\begin{array}{c}-5.71 \\
(-2.33)\end{array}$ & $\begin{array}{c}-5.74 \\
(-2.30)\end{array}$ & $\begin{array}{c}-5.73 \\
(-2.30)\end{array}$ \\
\hline GINILND & & & $\begin{array}{c}-8.14 \\
(-5.49)\end{array}$ & $\begin{array}{c}-6.41 \\
(-3.79)\end{array}$ & $\begin{array}{c}-6.39 \\
(-3.69)\end{array}$ & $\begin{array}{c}-6.46 \\
(-3.71)\end{array}$ \\
\hline $\begin{array}{l}\text { DEMOC* } \\
\text { GINILND }\end{array}$ & & & & & $\begin{array}{c}-0.11 \\
(-0.13)\end{array}$ & \\
\hline DEMOC & & & & & & $\begin{array}{c}-0.09 \\
(-0.15)\end{array}$ \\
\hline $\bar{R}^{2}$ & 0.28 & 0.23 & 0.43 & 0.46 & 0.45 & 0.45 \\
\hline
\end{tabular}

The dependent variable is average per capita growth rate over 1970-1985. t-statistics are in parentheses. Independent variables are defined as follows:

GDP70: $\quad$ Per capita GDP level in 1970

PRIM70: $\quad$ Primary school cnrollment ratio in 1970

GINI70: $\quad$ Gini coefficient of income inequality. meusured tose to 1970) (see Appendix for dates

GINILND: Gini coefficient of land distribution inequality, mensured eltose lo 1960 fsee Appendix for dale?: i DEMOC: Democracy dummy.

raise some questions about the generalizability of Persson and Tabellini's [1991] results on this front.

\section{Concluding Remarks}

The basic message of our model is that there will be a strong demand for redistribution in societies where a large section of the population does not have access to the productive resources of the economy. Such conflict over distribution will generally harm 
growth. Our empirical results are supportive of these hypotheses: they indicate that inequality in income and land distribution is negatively associated with subsequent growth.

An important extension of our model would be to examine more closely the dynamic interconnection between distribution and growth. In our model the distribution of assets is predetermined and remains constant. In reality growth itself affects income distribution. The serious technical problem introduced in this case is that when income distribution varies over time, as a function of growth, one cannot look at each voting decision in isolation. Voting decisions in any period affect growth in subsequent periods, which, in turn affects distribution and future voting decisions. Thus, the outcome of future social choices depends on the voting decisions taken today. Therefore, when voting today, rational voters have to internalize this dynamic problem of social choice. 
APPENDIX 1:

LISI OF COUNTRIES AND DA'TES FOR GINI COEFFICIEN'T FOR INCOME

(High-Quality SAMPLE: $N=46$ )

\begin{tabular}{|c|c|c|c|}
\hline \multirow[b]{2}{*}{ Country* } & \multicolumn{2}{|c|}{ Date measured } & \multirow[b]{2}{*}{ Source } \\
\hline & 1960-1985 Sample & 1970-1985 Sample & \\
\hline Australia (D) & $67-68$ & $67-68$ & J \\
\hline Bangladesh & $68-69$ & $68-69$ & $\mathbf{F}$ \\
\hline Brazil & 60 & 70 & $\mathrm{~F}$ \\
\hline Canada (D) & 61 & 65 & $J$ \\
\hline Chile (D) & 68 & 68 & $\mathrm{~F}$ \\
\hline Colombia (D) & 71 & 71 & $\mathrm{~F}$ \\
\hline Costa Rica (D) & 61 & 71 & $\mathrm{~F}$ \\
\hline Denmark (D) & 63 & 66 & $J$ \\
\hline Egypt & $58-59$ & $64-65$ & F \\
\hline El Salvador & $76-77$ & $76-77$ & F \\
\hline Fiji & 77 & 77 & F \\
\hline Finland (D) & 62 & 62 & $J$ \\
\hline France (D) & 62 & 62 & $J$ \\
\hline Germany (D) & 68 & 70 & $\mathrm{~J}$ \\
\hline Greece (D) & $57-58$ & $57-58$ & $J$ \\
\hline Honduras & $67-68$ & $67-68$ & $\mathrm{r}$ \\
\hline Hong Kong & 66 & 71 & F \\
\hline India (D) & $75-76$ & $75-76$ & F \\
\hline Indonesiat & 64 & 70 & $\mathrm{~F}$ \\
\hline Iran & $73-74$ & $73-74$ & $\mathrm{~F}$ \\
\hline Israel (I) & $57-58$ & 69 & $\mathrm{~J}$ \\
\hline Jamaica (D) & 68 & 68 & $\mathrm{~F}$ \\
\hline Japan (D) & 62 & 71 & $J$ \\
\hline Korea & 65 & 70 & $\mathbf{F}$ \\
\hline Malaysia (D) & $57-58$ & 70 & $\mathbf{F}$ \\
\hline Mexico & 58 & 69 & $\mathrm{~F}$ \\
\hline Nepal & $76-77$ & $76-77$ & $\mathrm{~F}$ \\
\hline Netherlands (D) & 62 & 67 & $\mathrm{~J}$ \\
\hline New Zealand (D) & 66 & 70 & $J$ \\
\hline Norway (D) & 57 & 63 & $\mathrm{~J}$ \\
\hline Pakistan & $63-64$ & $69-70$ & $\mathrm{~F}$ \\
\hline Panama & 70 & 70 & F \\
\hline Philippines & 57 & 71 & $\mathbf{F}$ \\
\hline Sierra Leone & $67-68$ & $67-68$ & $\mathrm{~F}$ \\
\hline Singapore & $72-73$ & $72-73$ & $\mathrm{~F}$ \\
\hline South Africa & 65 & 65 & $\mathrm{~J}$ \\
\hline Spain (D) & 64 & 64 & $J$ \\
\hline Sri Lanka (D) & 53 & 73 & $\mathbf{F}$ \\
\hline Sweden (D) & 63 & 70 & $J$ \\
\hline Taiwan & 64 & 72 & $\mathrm{~F}$ \\
\hline Thailand & $62-63$ & $68-69$ & $\mathrm{~F}$ \\
\hline Trinidad \& Tobago & $71-72$ & $71-72$ & $\mathrm{~F}$ \\
\hline Tunisia & $74-75$ & $74-75$ & $\mathrm{~F}$ \\
\hline Turkey (D) & 68 & 68 & $\mathrm{~F}$ \\
\hline U. K. (D) & 60 & 68 & $J$ \\
\hline U. S. A. (D) & 60 & 70 & $J$ \\
\hline
\end{tabular}

Sources. F = Field.s |1993|, $J=$ Jain | $1975 \mid$.

$* \mathrm{O}=$ democracies; all the others are nondemocracies. 
APPENDIX 2:

List of COUNTRIES AND Dates FOR GINI COEFFICIENT FoR

INCOME LARGER SAMPLE

$(N=70$ IN TOTAL $)$

INCLLDES THE PREVIOUS COLN'TRIES, PLUS:

\begin{tabular}{lcc}
\hline \hline & \multicolumn{2}{c}{ Date measured } \\
\cline { 2 - 3 } \multicolumn{1}{c}{ Country* } & $1960-1985$ Sample & 1970-1985 Sample \\
\hline Argentina & 61 & 61 \\
Barbados & $69-70$ & $69-70$ \\
Botswana & 71 & 71 \\
Burma & 58 & 58 \\
Chad & 58 & 58 \\
Côte d'Ivoire & 59 & 70 \\
Cyprus & 66 & 66 \\
Dominican Rep. & 69 & 69 \\
Ecuador & 65 & 70 \\
Gabon & 60 & 68 \\
Guatemala & 66 & 66 \\
Guyana & $55-56$ & $55-56$ \\
Iraq & 56 & 56 \\
Kenya & 69 & 69 \\
Malawi & 69 & 70 \\
Peru & 70 & 60 \\
Senegal & 60 & 63 \\
Sudan & 63 & 62 \\
Surinam & 62 & 69 \\
Tanzania & 67 & 67 \\
Uruguay & 67 & 71 \\
Venezuela & 62 & 59 \\
Zambia & 59 & 68 \\
Zimbabwe & 68 & -1 \\
\hline \hline
\end{tabular}

Source. Jain $\lceil 1975\rceil$.

*All these countries are nondemocracies. 
APPENDEX 3:

List of COUNTRIES AND D ${ }^{\prime}$ 'ES FOR GINI COEFFICIENTS FOR LAND $(N=49)$

\begin{tabular}{lc}
\hline \hline \multicolumn{1}{c}{ Country } & Date measured \\
\hline Argentina & 1960 \\
Australia & 1960 \\
Austria & 1960 \\
Belgium & 1960 \\
Brazil & 1960 \\
Colombia & 1960 \\
Costa Rica & 1963 \\
Dominican Republic & 1960 \\
Denmark & 1959 \\
Ecuador & 1954 \\
El Salvador & 1961 \\
Finland & 1959 \\
Guatemala & 1950 \\
Honduras & 1952 \\
Iran & 1959 \\
India & 1955 \\
Iraq & 1958 \\
Ireland & 1963 \\
Italy & 1960 \\
Jamaica & 1960 \\
Japan & 1960 \\
Kenya & 1960 \\
Luxembourg & 1960 \\
Malaysia & 1960 \\
Mali & 1960 \\
Malta & 1960 \\
Mexico & 1960 \\
Netherlands & 1959 \\
New Zealand & 1960 \\
Nicaragua & 1963 \\
Norway & 1959 \\
Pakistan & 1960 \\
Panama & 1961 \\
Peru & 1961 \\
Philippines & 1960 \\
South Africa & 1960 \\
South Korea & 1961 \\
Spain & 1960 \\
Sweden & 1961 \\
Taiwan & 1960 \\
Thailand & 1963 \\
Trinidad and Tobago & 1963 \\
Turkey & 1960 \\
United Arab Republic & 1964 \\
United Kingdom & 1960 \\
United States & 1959 \\
Uruguay & 1961 \\
Venezuela & 1956 \\
West Germany & 1960 \\
\hline \hline
\end{tabular}


Harvard University, National Bureal of Economic Research, and Centre for ECONOMIC POLICY RESEARCH

Columbia University, National Bureau of Economic Research, and Centre for ECONOMIC POLICY RESEARCH

\section{REFERENCES}

Alesina, Alberto, and Dani Rodrik, "Distributive Politics and Economic Growth," NBER Working Paper No. 3668, 1991.

Barro, Robert, "Government Spending in a Simple Model of Economic Growth," Journal of Political Economy, XCVIII (1990), 103-125.

"Economic Growth in a Cross Section of Countries," Quarterly Journal of Economics, CVI (May 1991), 407-44.

Barro, Robert, and Holger Wolf, "Data Appendix for Economic Growth in a Cross-Section of Countries," unpublished manuscript, 1989.

Barro, Robert, and Xavier Sala-i-Martin, "Public Finance in the Theory of Economic Growth," unpublished manuscript, 1990.

Benhabib, Jess, and Aldo Rustichini, "Social Conflict, Growth and Income Distribution," unpublished manuscript, 1991.

Bertola, Giuseppe, "Factor Shares, Saving Propensities, and Endogenous Growth," American Economic Review, LXXXIII (December 1993), 1184-98.

Clarke, George R. G., "More Evidence on Income Distribution and Growth," University of Rochester, unpublished paper, June 1993.

Fernandez, Raquel, and Richard Rogerson, "Human Capital Accumulation and Income Distribution," NBER Working Paper No. 3994, 1992.

Fields, Gary, Poverty, Inequality and Development (Cambridge, MA: Harvard University Press, 1980 ).

"A Compendium of Data on Inequality and Poverty for the Developing World," Cornell University, unpublished manuscript, 1989.

Fields, Gary, and George Jakubson, "New Evidence on the Kuznets Curve," Cornell University, unpublished manuscript, 1993.

Fischer, Stanley, "Dynamic Inconsistency, Cooperation and the Benevolent Dissembling Government," Journal of Economic Dynamics and Control, II (1980), 93-107.

Galor, Oded, and Joseph Zeira, "Income Distribution and Macroeconomics," Review of Economic Studies, LX (January 1993), 35-52.

Heston, Alan, and Robert Summers, "A New Set of International Comparisons of Real Product and Price Levels: Estimates for 130 Countries," The Review of Income and Wealth, XXXIV (1988), 1-25.

Jain, S., "Size Distribution of Income: A Comparison of Data," The World Bank, unpublished manuscript, 1975.

Lecallion, Jack, Felix Paukert, Christian Morrison, and Dimitri Gemiolis, "Income Distribution and Economic Development: Analytical Survey" (Geneva: International Labor Office, 1984).

Kuznets, Simon, "Economic Growth and Income Inequality," American Economic Review, XLV (1955), 1-28.

Lucas, Robert E., Jr., "On the Mechanics of Economic Development," Journal of Monetary Economics, XXII (1988), 3-42.

Mayer, Wolfgang, "Endogenous Tariff Formation," American Economic Review, LXXIV (1984), 970-85.

Meltzer, Allan H., and Scott F. Richard, "A Rational Theory of the Size of the Government," Journal of Political Economy, LXXXIX (1981), 914-27.

Murphy, Kevin M., Andrei Shleifer, and Robert Vishny, "Income Distribution, Market Size, and Industrialization," Quarterly Journal of Economics, CIV (August 1989), 537-64.

Perotti, Roberto, "Income Distribution, Politics, and Growth," American Economic Review Papers and Proceedings, LXXXII (May 1992), 311-16.

_, "Political Equilibrium Income Distribution and Growth," Review of Economic Studies, LX (October 1993), 755-76.

Persson, Torsten, and Guido Tabellini, "Is Inequality Harmful for Growth? Theory and Evidence," unpublished paper, May 1991. 
Ranis, Gustav, "Contrasts in the Political Economy of Development Policy Change," in Gary Gereffi and Donald L. Wyman, eds., Manufacturing Miracles: Paths of Industrializalion in Latin America and East Asia (Princeton, NJ: Princeton University Press, 1990).

Roberts, Kevin W. S., "Voting over Income Tax Schedules," sournal of Public Economics, VIII (1977), 329-40.

Rodrik, Dani, "Redistributive Taxation without Excess Burden," Economics \& Politics, V (March 1993), 53-60.

Romer, Paul M., "Increasing Returns and Long-Run Growth," Journal of Political Economy, XCIV (1986), 1002-37.

Romer, Thomas, "Individual Welfare, Majority Voting, and the Properties of a Linear Income 'Tax," Journal of Public Economics, XIV (1975), 163-85.

Saint-Paul, Gilles, and Thierry Verdier, "Education, Democracy and Growth," CEPR Discussion Paper No. 613, February 1992.

Stolper, Wolfgang, and Paul Samuelson, "Protection and Real Wages," Review of Economic Studies, IX (1941), 58-73.

Taylor, C. L., and M. C. Hudson, World Handbook of Political and Social Indicators, 2nd. ed. (New Haven, CT: Yale University Press, 1972).

Wade, Robert, Governing the Market: Economic Theory and the Role of Government in East Asian Industrialization (Princeton, NJ: Princeton University Press, 1990).

World Bank, World Development Report, 1990 (Washington, DC: The World Bank, 1990). 